\title{
Legal Profession Code of Ethics as Justice Enforcement for Professional Judges
}

\section{Kode Etik Profesi Hukum sebagai Penegakan Hukum yang Berkeadilan bagi Profesi Hakim}

\author{
Achmad Ghani \\ Universitas Islam Negeri Sunan Gunung Djati Bandung \\ E-mail: ghanihaikal07@gmail.com
}

\begin{abstract}
Ethics of living side by side and being tied to each other in the life of many people. Ethics has control over the creation of a mindset and treatment of the values of goodness that must be done and evil that must be avoided. The concept of ethical practice affects every professional in all fields, including the legal profession. The bearer of the legal profession is a person who has expertise and ability in the field of law. The knowledge that is owned is independently able to meet the needs of people who seek service and justice according to their expertise. Judges in their profession are deciding cases that are present at court. Of course, the fulfillment of the right to justice before the law is the ultimate goal of a profession that he carries. In deciding a case, a judge must be based on his knowledge, moral independence, and also the code of ethics for the judge's profession that is inherent in him in order to create a just decision based on divinity.
\end{abstract}

Keywords: ethics, legal profession, justice.

\begin{abstract}
ABSTRAK
Etika hidup berdampingan dan saling terikat dengan pergaulan hidup orang banyak. Etika memegang kendali atas terciptanya pola pikir dan perlakuan atas nilai-nilai kebaikan yang harus dilakukan dan kejahatan yang harus dihindarkan. Konsep pelaksanaan etika mempengaruhi setiap profesional yang bergerak di semua bidang, tidak terkecuali profesi hukum. Pengemban profesi hukum adalah orang yang memiliki keahlian dan kemampuan dalam bidang hukum. Keilmuan yang dimiliki tersebut secara mandiri mampu memenuhi kebutuhan masyarakat pencari pelayanan dan keadilan menurut keahliannya. Hakim dalam profesinya adalah memutus perkara yang hadir di persidangan. Tentunya, pemenuhan hak atas keadilan di hadapan hukum adalah tujuan akhir dari sebuah profesi yang diembannya. Seorang hakim dalam memutus perkara harus berlandaskan pada keilmuan yang dimiliki, kemandirian moral, dan juga kode etik profesi hakim yang melekat dalam dirinya agar terciptanya putusan yang berkeadilan berdasarkan ketuhanan.
\end{abstract}

Kata Kunci: Etika, Profesi Hukum, Berkeadilan.

\section{PENDAHULUAN}

Etika adalah filosofi tentang nilai, dan moralitas tentang yang baik dan yang jahat. Etika merupakan bagian dari falsafah yang mengajarkan ketuhanan. Akhlak artinya karakter atau tingkah laku. Perubahan moralitas atau perilaku manusia sangat mungkin terjadi, tergantung pemahaman etis setiap orang. Faktor penghubung antara etika, filsafat dan moralitas adalah rasionalitas. Ada persamaan antara etika, moralitas, dan filosofi, yang didasarkan pada kebenaran atau kebaikan di mana tindakan manusia dianggap tindakan yang benar dan salah. 
Etika adalah ilmu yang membahas tentang tingkah laku atau masalah perilaku manusia, yang dapat dinilai baik dan buruk, benar dan salah.

Dalam kehidupan manusia, moralitas berfungsi sebagai standar untuk menuntun perilaku. Etika membimbing individu ke dalam suatu situasi, dan bagaimana individu berperilaku dalam situasi tertentu. Etika memungkinkan orang untuk memahami bagaimana menjalani serangkaian aktivitas sehari-hari. Artinya, moralitas dapat membantu orang mengadopsi sikap yang benar dan mengambil tindakan dalam hidup. Akhirnya, etika dapat membantu kita membuat keputusan tentang tindakan apa yang perlu kita ambil dan apa yang perlu kita pahami bersama untuk menerapkan etika ini ke semua aspek kehidupan. Moralitas, moralitas dan moralitas adalah cara menjalin keharmonisan antara sesama manusia dan hubungan vertikal dengan Tuhan.

Para profesional hukum harus menjalankan pekerjaannya sesuai dengan kode etik profesinya, jika melanggar kode etik, harus bersedia bertanggung jawab atas akibat yang ditimbulkan sesuai dengan persyaratan kode etik. Suatu profesi dituntut untuk bertindak baik dan mampu menjalankan tugasnya dengan baik secara profesional untuk menghormati martabat manusia, sehingga tercipta keadilan dalam masyarakat. Ketika ada regulasi normatif yang mengindikasikan melanggar informasi moral, maka perilaku manusia bisa disebut baik, dan arif. Begitu pula jika prinsip moral sebelumnya telah mengatakan demikian, maka dapat dikatakan seseorang telah melanggar kode moral.

Etika profesi hukum (kode etik profesi) merupakan bagian penting dari pengaturan penegakan hukum, dan wujud penegakan hukum yang baik dan adil. Penegakan hukum membutuhkan sikap etika dan kejujuran, dan sikap ini menjadi modal bagi aparat penegak hukum untuk menjalankan tugas profesionalnya.

Tolok ukur utama aparatur penegak hukum adalah kemandirian tenaga administrasi yang profesional dan integritas moral yang kuat dalam menangani berbagai persoalan yang menjadi tanggung jawabnya. Untuk menjadi penyelenggara profesional hukum yang baik yang menjalankan tugas profesional di bidang penegakan hukum, perlu memiliki praktisi yang berkualitas dalam sikap, sikap kemanusiaan, sikap peradilan dan bidang lainnya, mampu mempersepsikan dan mengutamakan perkara, kejujuran, kematangan teknis dan moral dan pertimbangkan nilai obyektif (Burhanuddin, 2018).

Putusan pengadilan harus memuat setidaknya tiga unsur dari tujuan hukum yakni, keadilan, kepastian dan kemanfaatan. Tugas utama seorang hakim adalah menegakkan keadilan dalam ranah peradilan. Dalam penelitian ini, akan dibahas tentang bagaimana peranan kode etik profesi hukum sebagai penegakan hukum yang berkeadilan bagi profesi hakim.

\section{METODE PENELITIAN}

Metode penelitian yang digunakan adalah metode deskriptif analisis. Metode penelitian deskriptif analisis adalah metode yang digunakan untuk mendeskripsikan atau menggambarkan objek yang diteliti melalu data atau peristiwa dengan kesimpulan (Soekanto, 2019). Penelitian ini akan mengkaji mengenai kode etik profesi hukum sebagai penegakan hukum yang berkeadilan bagi profesi hakim. Pendekatan yang dilakukan adalah melalui pendekatan yuridis normatif, yakni Hhukum dikonsepsikan sebagai peraturan yang tertulis dalam peraturan perundang-undangan, meneliti bahan kepustakaan dan bahan hukum sekunder (Amirudin dan Asikin, 2012).

\section{HASIL DAN PEMBAHASAN}

Hakim adalah wakil Tuhan di bumi sebagai penentu keadilan dalam sebuah persidangan. Putusan hakim menjadi hukum bagi mereka yang bersengketa di pengadilan. Putusan yang dijatuhkan secara objektif tanpa dicemari kepentingan pribadi dan golongan manapun, karenanya putusan hakim haruslah berlandaskan Ketuhanan Yang Maha Esa. Dengan posisi demikian, profesi hakim dituntut untuk tidak takut pada siapapun, bahkan memberikan keputusan yang melawan penguasa (Manan, 2007).

Kode etik dan pedoman perilaku hakim menurut Pasal 1 butir 6 Undang-Udang Nomor 18

Copyright (C) 2020, JCIC - Jurnal CIC Lembaga Riset dan Konsultan Sosial 36 
Tahun 2011 Tentang Komisi Yudisial diartikan sebagai panduan yang digunakan dalam rangka menjaga dan menegakkan kehormatan, keluhuran martabat, serta perilaku hakim dalam melaksanakan tugasnya sebagai seorang hakim dan dalam hubungan kemasyarakatan di luar kedinasan (Anugrah, 2016).

Batasan profesi mereka dalam profesi hukum adalah kode etik, yaitu kode etik profesi hukum yang memuat kewajiban, larangan dan kewajiban kepada orang yang bertanggung jawab atas profesinya, serta sanksi bagi orang yang tidak melaksanakan tugas atau melanggar larangan tersebut. Untuk memberikan jiwa penegakan hukum kepada hukum, maka perlu memperhatikan persoalan etika, akhlak dan moral. Dalam rangka memenuhi tuntutan hukum guna mendukung demokratisasi, maka persoalan moral dan etika sangat dibutuhkan untuk ditingkatkan fungsi dan eksistensinya, karena aspek moral dan etika saat ini telah menghilang dari sistem hukum Indonesia.

Adanya kode etik suatu profesi diharapkan akan terwujudnya nilai-nilai moral yang dianggap hakiki sehingga dapat mewujudkan cita-cita masyarakat atas hukum yang berkeadilan. Kode etik yang memiliki nilai luhur yang mendarah daging pada profesional hukum menjadi harapan untuk dilaksanakan dengan konsekuen. Semakin berat dan kompleksnya permasalahan yang dihadapi, kehadiran kode etik menjadi lebih penting sehingga pengamplikasian kode etik terhadap aspek fungsional profesi hukum menjadi lebih terbuka.

Muhammad Nuh dalam bukunya etika profesi hukum mengatakan bahwa etika profesi ialah kesanggupan untuk memenuhi kebutuhan kliennya. Kaidah-kaidah pokok dalam etika profesi adalah: 1) Profesi yang dilakoni merupakan penghayatan terhadap suatu pelayanan yang tidak didasarkan atas pamrih. Pertimbangan yang dilakukan adalah untuk kepentingan klien dan kepentingan umum, bukan atas kepentingan pribadi, agar tidak terjadi penyalahgunaan profesi yang merugikan orang lain. 2) Pelayanan profesional harus mendahulukan kepentingan klien yang mengacu pada kepentingan luhur manusia yang membatasi tindakan yang dilakukan. 3) Pengemban profesi harus berorientasi kepada masyarakat luas. 4) Pengemban profesi harus memiliki sikap solidaritas sesama profesional (Nuh, 2011).

Tolok ukur pelaksanaan profesi hukum yang baik sebagai mana menurut Ucuk Agiyanto terletak pada independensi penegak hukumnya. Setiap negara tentu memiliki cita-cita penegakan hukum dan juga penegak hukum atau penyelenggara hukum yang baik. Penyelenggara profesi hukum menjadi titik pusat dalam penyelesaian permasalahan yuridis dalam masyarakat, sehingga orientasi penyelenggara profesi hukum adalah keadilan luhur bagi masyarakat pencari keadilan. Friedman merujuk pada faktor-faktor keberlakuan hukum, yang meliputi struktur hukum, substansi hukum dan budaya hukum terhadap pembentukan dan penegakan hukum yang didasarkan pada nilai-nilai keadilan dan ketertiban serta keefektifannya dalam masyarakat.

Produk hukum yang digali dari masyarakat seyogyanya kembali kepada masyarakat dalam bentuk keadilan berdasarkan ketuhanan dan kemanusiaan. Dalam hal ini, pelaksanaan hukum membutuhkan penegak hukum yang mampu bekerja keras dalam mewujudkan keadilan yang tidak hanya berorientasi pada yuridis normatif, tetapi juga norma yang hidup dalam masyarakat. Dalam penegakan hukum, banyak faktor yang mempengaruhi. Tidak hanya peraturan perundang-undangan saja, tetapi juga pelaksanaan penegakan hukum oleh aparat penegak hukum, dan budaya masyarakat yang ikut mempengaruhi penegakan hukum. Penegakan hukum merupakan rangkaian proses menerapkan ide-ide, nilai, dan cita hukum yang abstrak menjadi tujuan hukum (Nuryanto, 2018).

Asas equality before the law dalam penegakan hukum harus senantiasa dilakukan karena manusia haruslah dimanusiakan dan dipenuhi hak-haknya. Salah satu aspek penting dalam rangka penegakan hukum adalah proses pembudayaan, pemasyarakatan dan pendidikan hukum (law socialization and law education) (Prasetyaningsih, 2011).

Dalam rangka penegakan hukum di Indonesia, peran hakim dalam lembaga peradilan merupakan kunci vital dalam memutus perkara yang adil dan bermartabat. Seorang hakim yang merupakan pengadil di persidangan dalam menjalankan tugasnya dibatasi oleh norma dan etika profesinya, mengingat dengan kewenangan-kewenangan yang dimilikinya. Melalui putusannya, hakim dapat mengubah atau bahkan mengalihkan dalam rangka menegakkan hukum dan 
keadilan (Hendrawati dkk., 2011).

Komisi Yudisial merupakan lembaga yang memiliki wewenang untuk mengajukan pengangkatan hakim Agung kepada DPR, menjaga dan menegakkan kehormatan hakim, serta perilaku hakim. Komisi Yudisial bukanlah lembaga penegak hukum, melainkan lembaga penegak etika kehakiman. Pengawasan oleh komisi yudisial terhadap hakim dilakukan dengan upaya preventif dan represif. Upaya preventif dengan memberikan pendidikan kepada calon hakim dan pelatihan secara berkala. Sedangkan sedangkan upaya represif dilakukan dengan pendisiplinan terhadap Hakim yang melakukan pelanggaran terhadap kode etik Hakim. Hakim yang melakukan pelanggaran terhadap etika profesi, mendapatkan pendisiplinan oleh Komisi Yudisial dengan sanksi yang tertuang dalam surat keputusan bersama. (Taufiqurrahman Syahuri, 2011).

Forum International Judicial Conference di Banglore India tahun 2011, telah disepakati kode etik dan perilaku hakim sedunia yang dikenal dengan The Banglore Draft yang di dalamnya terdapat enam prinsip hakim yang harus dipegang secara universal, yaitu: 1) Independensi (Independence Principle); 2) Ketidakberpihakan (Impartially Principle); 3) Integritas (Integrity Principle), 4) Kepantasan dan Kesopanan (Propriety Principle), 5) Kesetaraan (Equality Principle), dan 6) Kecakapan dan Keseksamaan (Competence and Diligent Principle) (Asshiddiqie, 2009).

Berdasarkan surat keputusan bersama (SKB) antara Ketua Mahkamah Agung (MA) dan Ketua Komisi Yudisial (KY) Nomor 047/KMA/SKB/IV/2009 dan Nomor 02/SKB/P.KY/IV/2009 Tentang Kode Etik dan Pedoman Perilaku Hakim, surat keputusan bersama ini mengatur tentang kode etik dan pedoman perilaku hakim yang terdiri dari 10 (sepuluh) aturan perilaku, yaitu: Berperilaku Adil, Berperilaku Jujur, Berperilaku Arif dan Bijaksana, Bersikap Mandiri, Berintegrasi Tinggi, Bertanggung Jawab, Menjunjung Tinggi Harga Diri, Berdisiplin Tinggi, Berperilaku Rendah Hati dan Bersikap Profesional.

Pasal 1 butir 1 Undang-Undang Nomor 48 Tahun 2009 Tentang Kekuasaan Kehakiman menyatakan dengan tegas bahwa kekuasaan kehakiman adalah kekuasaan negara yang merdeka untuk menyelenggarakan peradilan menegakkan hukum dan keadilan berdasarkan Pancasila dan Undang-Udang Dasar Negara Republik Indonesia Tahun 1945, demi terciptanya Negara Hukum Republik Indonesia.

Penjelasan Angka 1 UU Nomor 48 Tahun 2009 berisi keterangan yang menegaskan adanya independensi/kemerdekaan lembaga-lembaga peradilan. Independensi kekuasaan kehakiman yang dijamin oleh hukum dasar negara Indonesia dan aturan-aturan turunan di bawahnya, dilaksanakan oleh hakim-hakim pengadilan dalam lingkup Peradilan yang terlepas dari pengaruh pemerintah dan pengaruh lainnya.

Oemar Seno Adji mengatakan bahwa hakim dalam memutus perkara yang ditanganinya memiliki kebebasan untuk memutus perkara tersebut tanpa intervensi dari pihak manapun. Hakim berfungsi sebagai pelaksana penerapan teks Undang-Udang ke dalam peristiwa konkrit, tidak hanya bersifat substantive (Bustami, 2017).

Sejalan dengan hal itu, hakim dituntut untuk melakukan penggalian hukum, mengikuti dinamika sosial, dan nilai-nilai keadilan yang hidup dalam masyarakat. Hal ini dipertegas oleh Pasal 5 Undang-Udang Nomor 48 Tahun 2009, bahwa: 1) Hakim dan hakim konstitusi wajib menggali, mengikuti dan memahami nilai-nilai hukum dan rasa keadilan yang hidup dalam masyarakat. 2) Hakim dan hakim konstitusi harus memiliki integritas dan kepribadian yang tidak tercela, jujur, adil, profesional, dan berpengalaman di bidang hukum. 3) Hakim dan hakim konstitusi wajib menaati kode etik dan pedoman perilaku hakim.

Tuntutan tersebut merupakan tuntutan hukum dan profesionalitas yang harus dipegang oleh para profesional hukum dalam menjalankan fungsi kekuasaan kehakiman. Penghayatan dalam memaknai independensi yang benar dan tidak keliru terhadap kekuasaan kehakiman dapat mengangkat citra lembaga peradilan yang Agung.

Menurut Profesor Franz Magnis Suseno, setidaknya ada lima nilai moral profesi, diantaranya adalah: Kejujuran. Jujur berarti berani mengatakan benar atau salah. Kejujuran mendorong pembentukan kepribadian yang kuat dan meningkatkan kesadaran masyarakat tentang sifat benar dan salah. Oleh karena itu, sikap pribadi yang jujur, yang tidak mendukung semua orang selama persidangan dan di luar persidangan akan terwujud. Hakim harus selalu benar dan jujur di dalam dan di luar pengadilan. 
Otentik. Otentik bermakna menunjukkan diri sesuai dengan apa yang ada. Menjadi benar berarti menunjukkan diri apa adanya. Hakim harus mampu bertindak sesuai dengan norma sosial, norma hukum, norma agama, adat istiadat, dan etika dengan memperhatikan keadaan dan kondisi yang berlaku, serta mampu memperhitungkan akibat dari perbuatannya.

Bertanggung jawab. Dari segi nilai moral atau etika profesi, hakim harus bisa bertanggung jawab atas segala sesuatu yang ada di dalam dirinya. Hakim harus menjalankan tugasnya secara profesional, tidak membedakan perkara yang ditanganinya, melakukan semaksimal mungkin semua tugas yang sudah menjadi kewenangannya, dan berani menanggung segala akibat dari menjalankan kewenangannya. Tindakan hakim yang bertanggung jawab harus menginspirasi hakim untuk mengadili perkara agar dapat mengambil keputusan yang adil, benar dan kepastian hukum, sehingga membawa manfaat, inilah tujuan akhir dari undang-undang.

Kemandirian Moral. Kemandirian moral berarti tidak mudah dipengaruhi oleh konsep moral yang melingkupinya. Kemandirian moral akan mendorong terbentuknya individu yang berani menahan godaan dan mengintervensi dalam berbagai bentuk. Hal itu dilakukan untuk menjaga kepercayaan masyarakat terhadap penegakan hukum dan aparat penegak hukum.

Keberanian Moral. Setiap penegak hukum harus berani mengambil keputusan dan risiko apa saja yang akan terjadi. Hakim harus bertindak dengan hati nurani dan sikap profesionalnya sendiri untuk menyelesaikan setiap tugasnya yang dilandasi oleh tekad untuk melaksanakan pekerjaan pilihannya dengan keikhlasan dan keilmuan yang profesional.

Hakikat dan inti hukum adalah keadilan bagi banyak orang. Penegak hukum khususnya hakim harus mampu memahami kebutuhan hukum dan keadilan dalam masyarakat pada umumnya. Dalam praktik penegakan hukum, masih terdapat kecenderungan untuk memutus perkara berdasarkan kepastian hukum, bukan untuk keadilan dan kemanfaatan bagi orang banyak. Menegakkan hukum yang hanya berpacu pada kepastian hukum justru mengakibatkan hukum tersebut kehilangan makna hukum itu sendiri, yakni keadilan, kebahagiaan, kemanfaatan, dan pemenuhan hak asasi manusia. Keadilan dalam konteks hukum sangat terikat erat dengan asas legalitas. Seseorang dikatakan mendapatkan perlakuan atau akibat hukum yang adil ketika bersalah apabila telah ada aturan hukum yang mengatur sebelumnya (Hayat, 2015).

Prinsip keadilan sering kali dijadikan celah oleh masyarakat untuk memperoleh keadilan kepada negara atau penegak hukum dan pelaksana Undang-Udang. Konsep keadilan yang hidup di masyarakat saat ini adalah perbandingan terhadap nilai-nilai keadilan yang dijatuhkan pada orang yang berbeda dalam peraturan yang sama.

\section{KESIMPULAN}

Profesi hakim merupakan profesi mulia yang sering disebut sebagai wakil Tuhan di muka bumi. Dengan nomenklatur tersebut, mengandung makna begitu pentingnya peran profesi hakim sebagai penentu dan pemutus benang perkara yang hadir di persidangan. Penegakan hukum oleh hakim merupakan akhir dalam suatu peradilan setelah proses panjang sebelumnya. Dari uraian tersebut di atas dapat ditarik kesimpulan bahwa penegakan hukum yang baik bisa didapat dari hakim yang ideal, yakni memiliki keilmuan yang luas, berperilaku adil, berperilaku jujur, arif dan bijaksana, bersikap mandiri, berintegritas tinggi, bertanggung jawab, menjunjung tinggi harga diri, dan dapat bersikap profesional. Apabila dalam praktiknya hakim dapat menjalankan kode etik yang melekat pada dirinya, maka para pihak yang berkepentingan di muka persidangan akan memperoleh putusan yang berkeadilan. Dengan penegak hukum dan penegakan hukum yang baik pula, maka marwah lembaga peradilan akan terjaga dengan baik.

\section{DAFTAR PUSTAKA}

Agiyanto, U. (2013). PENEGAKAN HUKUM DI INDONESIA: Eksplorasi Konsep Keadilan Berdimensi Ketuhanan. Hukum Ransendental, (4), 493-503.

Amirudin dan Aasikin, Z. (2012). Pengantar Metode Penelitian Hukum. Jakarta: Raja Grafindo Persada

Anugrah M, M, P. (2019). Pertanggungjawaban Hakim Pelaku Pelanggaran Kode Etik Berpotensi Pidana. Jurnal Hukum. Universitas Atma Jaya Yogyakarta. 
Asshiddiqie, J. (2009). Pengantar Ilmu Hukum Tata Negara. Jakarta: PT. Raja Grafindo Persada.

Achmad Asfi Burhanudin. (2018). Peran Etika Profesi Hukum Sebagai Upaya Penegakan Hukum Yang Baik. El-Faqih: Jurnal Pemikiran Dan Hukum Islam, 4(2), 50-67. https://doi.org/10.29062/faqih.v4i2.25

Bustami, D. (2017). Kekuasaan Kehakiman Dalam Perspektif Negara Hukum Di Indonesia. Fakultas Hukum Universitas Muslim Indonesia. Masalah-Masalah Hukum. Jilid 46 (4).

Hayat, H. (2015). Keadilan Sebagai Prinsip Negara Hukum: Tinjauan Teoritis dalam Konsep Demokrasi.PADJADJARAN Jurnal Ilmu Hukum (Journal of Law),2(2), 388-408. https://doi.org/10.22304/pjih.v2n2.a10

Hendrawati Siti Vickie; Cahyo Yudhanto, Muhammad; Sunarko Putra, Nico, H. D. M. A., \& Sunarko Putra Muhammad; Dina Maulaya Adhisyah, Siti Vickie; Hendrawati, Heni, N. C. Y. (2016). ASPEK PENEGAKAN KODE ETIK HAKIM DALAM MEWUJUDKAN KEKUASAAN KEHAKIMAN YANG BERMARTABAT DAN BERINTEGRITAS. Varia Justicia, (Vol 12 No 1 (2016): Vol 12 No. 1 Maret 2016), 100-134. Retrieved from http://journal.ummgl.ac.id/index.php/variajusticia/article/view/346

Manan, A. (2007). Etika Hakim Dalam Menyelenggarakan Peradilan: Suatu Kajian Dalam Sistem Peradilan Islam. Jakarta: Prenada Media Grup.

Nuh, M. (2011). Etika Profesi Hukum. Bandung: Pustaka Setia

Oleh, P. H., Dalam, H., Nuryanto, C., Antara, P., Hukum, K., \& Keadilan, D. (2018). Penegakan Hukum Oleh Hakim Dalam Putusannya Antara Kepastian Hukum Dan Keadilan.Jurnal Hukum Khaira Ummah (Vol. 13, pp. 71-84). Retrieved from http://lppmunissula.com/jurnal.unissula.ac.id/index.php/ihku/article/view/2585

Prasetianingsih, R. (2011). AKUNTABILITAS KEKUASAAN KEHAKIMAN. Jurnal Konstitusi, 8(5), 829-848. https://doi.org/10.31078/jk

Soekanto, S. (2019). Pengantar Penelitian Hukum. Jakarta: UI-Press Cet.3

Taufiqurrahman S. (2011). Penguatan Fungsi Dan Tugas Konstitusional Komisi Yudisial. Jakarta: Komisi Yudisial Republik Indonesia 